\title{
Development of novel interferon alpha2b muteins and study the pharmacokinetic and biodistribution profiles in animal model
}

\author{
Ratih Asmana Ningrum ${ }^{1}$, Desi Eria Rahmatika ${ }^{1}$, Debbie Sofie Retnoningrum ${ }^{1}$, \\ Aang Hanafiah Wangsaatmadja ${ }^{2}$, Yeyet Cahyati Sumirtapura ${ }^{1}$, Heni Rachmawati $^{1 *}$ \\ ${ }^{1}$ School of Pharmacy, Bandung Institute of Technology, Bandung, Indonesia \\ ${ }^{2}$ Labeled Compound and Radiometry Division, National Nuclear Energy Agency, Bandung, Indonesia \\ Email: ${ }^{*}$ h_rachmawati@fa.itb.ac.id
}

Received 28 October 2011; revised 30 November 2011; accepted 6 January 2012

\begin{abstract}
Novel human interferon alpha2b (hIFN $\alpha 2 b)$ muteins were developed by substituting cysteine residue (C) at positions 2 and 99 with aspartic acid residues (D). The mutein forms were then studied for pharmacokinetic profile. In addition, the influence of charge on the protein structure was tested in vivo for the biodistribution pattern. Codon substitutions were performed by Polymerase Chain Reaction (PCR)-based site-directed mutagenesis on a previously constructed synthetic hIFN $\alpha 2 b$ open reading frame (ORF) cloned in pET32b expression plasmid. The result of nucleotide sequencing analysis confirmed that all codons were replaced successfully without any additional mutation. Three mutant forms of hIFN $\alpha 2 b$ ORF were overexpressed in Escherichia coli BL21 (DE3) resulted in three muteins: hIFN $\alpha 2 b$ C2D, hIFN $\alpha 2 b$ C99D, hIFN $\alpha 2 b$ C2D C99D. To follow the kinetic and localization of the mutein interferon after intravenous administration, Tc99m was used to label the proteins. In particular of elimination half-life, it was shown that hIFN $\alpha 2 b$ C2D C99D > hIFN $\alpha 2 b C 2 D>$ hIFN $\alpha 2 b C 99 D>$ wild type. hIFN $\alpha 2 b$ C2D C99D mutein showed highest blood accumulation after 30 minutes administration. Taken together, the charge of hIFN $\alpha 2 b$ seems to be responsible for the fate of hIFN $\alpha 2 b$ in vivo.
\end{abstract}

Keywords: Mutein; Human Interferon Alpha2b; Amino Acid Substitution; PCR Based Site Directed Mutagenesis; $\mathrm{Tc}^{99 \mathrm{~m}}$ labeling; Pharmacokinetic; Biodistribution; Protein Charge

\section{INTRODUCTION}

Interferon (IFN) is a cytokine produced and secreted by

"Corresponding author. almost all eucaryotic cells as a response to viral, bacterial, antigen, or mitogen stimuli. Based on their receptor types on the cell membrane surface, IFN is classified into type I which consists of IFN $\alpha, \operatorname{IFN} \beta, \operatorname{IFN} \tau, \operatorname{IFN} \omega$ and type II which consists of IFN $\gamma$. hIFN $\alpha 2 b$, as a subclass of IFN $\alpha$, is a glycoprotein consisting of 165 amino acids with size of 19271 Dalton. The molecule's O-glycosylation at threonine position 106 is not important for its biological activity. hIFN $\alpha 2 \mathrm{~b}$ has two disulfide bridges formed by cysteins (between positions 1 and 98, and between 29 and 138). hIFN $\alpha 2 \mathrm{~b}$ is used as standard therapeutic protein for hepatitis $\mathrm{B}$ and hepatitis $\mathrm{C}$ treatments. In addition, the potential use to treat several types of cancer e.g. multiple myeloma, chronic myeloid leukemia, non-Hodgkin's lymphoma, renal cell carcinoma, epidermoid cervical cancer, head and neck tumours, melanoma and medullary thyroid carcinoma was also demonstrated [1-3]. However, therapeutical outcome of hIFN $\alpha 2 b$ is not satisfied due to rapid elimination through renal clearance. Several strategies to improve $\mathrm{hIFN} \alpha 2 \mathrm{~b}$ half-life have been reported, including pegylation, albumin fusion and glycosylation [3-5].

Previously, a synthetic ORF based on optimized codon for high expression in $E$. coli encoding for hIFN $\alpha 2$ b was successfully constructed using thermodynamically balanced inside out method. The ORF was cloned and overexpressed in $E$. coli BL21 (DE3). The recombinant hIFN $\alpha 2 \mathrm{~b}$ was produced as a fusion protein of $37 \mathrm{kDa}$ containing f-methionine as first amino acid, thioredoxin and polihistidine tags at its $\mathrm{N}$ terminus. The protein was confirmed as hIFN $\alpha 2 \mathrm{~b}$ using Nano LC MS/MS resulting $80 \%$ amino acids coverage [6]. In this report, novel muteins of this protein were developed to improve the negative charge on the protein. The main aim was to prevent renal clearance thus improving the plasma half-life.

There are 12 amino acids (Leu30, Lys31, Arg33, His34, Phe36, Arg120, Lys121, Gln124, Tyr122, Tyr129, Lys131, 
and Glu132) in hIFN $\alpha 2 \mathrm{~b}$ are involved in the biological activity [7]. Among 4 cysteine residues, cysteine at position 1 and 98 which form a disulfide bridge was not required in biological activity of interferon alpha2b [8]. Even, the disruption of this disulfide bridge by serine substitutions resulted in higher antiviral activity [9]. In this report, we substituted those cysteines with aspartic acid to improve the net negative charge of the protein. Aspartic acid is the amino acid having lowest $\mathrm{pI}$ i.e. 2.77. By substituting of other amino acids with aspartic acid, the net charge of hIFN- $\alpha 2 \mathrm{~b}$ will be more negative. The expectation was to introduce a repulsion force on interferon when approaching basal renal membrane which is covered by negative protein matrices. To do so, PCR-based site-directed mutagenesis (SDM) was applied. SDM-based on PCR is widely used to test the role of particular residues in the structure, activity and ligand-binding capacity of a protein by introducing mutation into target DNA [10]. Comparing to mutant selective by mutagenic agents, SDM method is much more effective yielding desired mutation in the successful range of 50\% - 100\% [11]. Three mutant forms of hIFN $\alpha 2 \mathrm{~b}$ we developed, namely C2D, C99D, and C2D C99D, will be compared for the enhancement in the pharmacokinetic profile and the accumulation pattern in the body after intravenous injecttion.

\section{MATERIAL AND METHOD}

\subsection{Bacterial Strains and Plasmids}

$\mathrm{pET} 32 \mathrm{~b}-\mathrm{hIFN} \alpha 2 \mathrm{~b}$ recombinant plasmid from previous work was used as a template for SDM [6]. Luria Bertani (LB) broth containing $100 \mu \mathrm{g} / \mathrm{mL}$ of ampicillin was used for cultivation and LB containing $0.5 \mathrm{mM}$ of isopropyl thiogalactopyranoside (IPTG) was used as an inducer in gene expression step.

\subsection{Animals}

Male Wistar rats with age of 6 - 8 weeks and 250 - $300 \mathrm{~g}$ were used for pharmacokinetic study. While, Swiss mice weighing of 30 - $40 \mathrm{~g}$ were used for biodistribution assay. Animals used in the experiments received care in compliance with the "Principles of Laboratory Animal Care" and "Guide for the Care and Use of Laboratory Animals".

\subsection{Site-Directed Mutagenesis}

Mutagenic primers were designed using DNA Star (DNA Star Inc, USA) as shown in Table 1. First PCR-based SDM was applied to substitute $\mathrm{TGT}_{2}$ into GAT. Recombinant $p E T 32 b$ carrying hIFN $\alpha 2 b$ ORF was used as a template. PCR was done in $50 \mu \mathrm{l}$ reaction volume containing $400 \mu \mathrm{M}$ dNTP, $1 \times P f u$ buffer, $2.5 \mathrm{U}$ of $P f u$ DNA poly- merase, $150 \mathrm{ng}$ of SDMPFORC2D primer, $150 \mathrm{ng}$ of SDMPREVC2D primer, and $50 \mathrm{ng}$ template. PCR was performed as follow: initial denaturation at $95^{\circ} \mathrm{C}$ for $30 \mathrm{~s}$, 12 cycles of denaturation at $95^{\circ} \mathrm{C}$ for $30 \mathrm{~s}$, annealing at $55^{\circ} \mathrm{C}$ for $1 \mathrm{~m}$, and polymerization at $68^{\circ} \mathrm{C}$ for $6.5 \mathrm{~m}$. PCR product was treated by $10 \mathrm{U} D p n \mathrm{I}$ at $37^{\circ} \mathrm{C}$ for $1 \mathrm{~h}$ and transformed into $E$. coli Top 10. Transformants were characterized based on plasmid size, and subsequently digested using EcoRI or HindIII. Nucleotide sequencing of the insert was then performed to evaluate the mutation. Recombinant pET32b that contained mutated hIFN $\alpha 2 b$ C2D ORF and pET32b carrying wildtype hIFN $\alpha 2 b$ ORF were used as templates in second SDM step, which was substituting $\mathrm{TGC}_{99}$ into GAC. The PCR was performed as described above. The mutagenic primers used were SDMPFORC99D and SDMREVC99D. The PCR was performed at $54^{\circ} \mathrm{C}$ for $1 \mathrm{~min}$ for annealing.

\subsection{Protein Overproduction, Purification and Characterization}

The protein overproduction was performed using optimized condition we obtained previously [12]. E. coli BL21(DE3) containing mutated plasmids overnight culture was added $(3 \% \mathrm{v} / \mathrm{v})$ to $1 \mathrm{~L}$ of LB broth containing $100 \mu \mathrm{g} \cdot \mathrm{mL}^{-1}$ of ampicillin. The culture was incubated for about $1.5 \mathrm{~h}$ in a shaking incubator at $37^{\circ} \mathrm{C} 200 \mathrm{rpm}$ and IPTG to $0.5 \mathrm{mM}$ final concentration was added to midlog phase of cell culture. Incubation was continued for an additional $3 \mathrm{~h}$. Cell pellet was harvested by centrifugation at $5000 \mathrm{~g}$ for $10 \mathrm{~min}$. The cells were resuspended in lysis buffer ( $50 \mathrm{mM} \mathrm{NaCl}$ and $1 \mathrm{mM}$ EDTA) and lyzed by sonication at $2.5 \mathrm{Hertz}$ in the presence of $1 \mathrm{mM}$ of phenylmethyl sulphonyl fluoride. To prevent temperature elevation, the cells were sequentially sonicated and cooled on ice for 10 times, each time for $30 \mathrm{~s}$. Soluble proteins were separated from IB by centrifugation at 10,000 g. The soluble protein was purified using Nickel column according to the manufacturer's protocol (Protino, Germany). To recover IB the pellet were washed with washing buffer (lysis buffer containing $0.5 \%$ Triton $\mathrm{X}-100 \mathrm{pH} 7.2$ ) and resuspended in solubilizing buffer (guanidine $\mathrm{HCl}$ buffer consisted of $6 \mathrm{M} \mathrm{GdnHCl}$ in $50 \mathrm{mM}$ Tris- $\mathrm{HCl} \mathrm{pH} 8$ containing $800 \mathrm{mM}$ of 2-Mercaptoethanol (2-ME) for $30 \mathrm{~min}$ at

Table 1. Oligonucleotides of PCR-Based SDM used to mutate hIFN $\alpha 2 b$.

\begin{tabular}{cc}
\hline Primers & \multicolumn{1}{c}{ Nucleotide sequence $\left(\mathbf{5}^{\prime} \rightarrow \mathbf{3}{ }^{\prime}\right)$} \\
\hline SDMPFORC2D & CGA ATT CCC ATA TGG ATG ACC TGC CGC \\
SDMPREVC2D & GCG GCA GGT CAT CCA TAT GGG AAT TCG \\
SDMPFORC99D & C CTG GAG GCG GAC GTT ATC CAA GGT G \\
SDMPREVC99D & C ACC TTG GAT AAC GTC CGC CTC CAG G \\
\hline
\end{tabular}


room temperature. Subsequently, solubilized pellet was centrifugated at $15,000 \mathrm{~g}$ for $15 \mathrm{~min}$ and $4^{\circ} \mathrm{C}$ to separate hIFN $\alpha 2 b$ and unsolubilized material. hIFN $\alpha 2 b$ from IB was refolded by 9 days dialysis in refolding buffer $(0.2$ mM EDTA, $0.25 \mathrm{mM}$ Ditiothreitol, $50 \mathrm{mM}$ Tris and 0.4 $\mathrm{M}$ urea; $\mathrm{pH}$ 8.0). The All crude proteins and purified muteins (as soluble and IB) were analyzed using 15\% Sodium Dodecyl Sulphate Polyacrylamide Gel Electrophoresis (SDS-PAGE) under denaturing condition. To evaluate the protein conformation, purified muteins were also characterized using 10\% native PAGE. Imidazol was removed from purified protein using nanosep centrifugal concentration with $10 \mathrm{kDa}$ cut off (Pall life science). Protein concentration was determined using Bradford method based on coomassie blue staining.

\subsection{IFN $\alpha 2 b$ Radiolabeling}

Interferons were labeled using ${ }^{99 \mathrm{~m}} \mathrm{Tc}$ radioactive. Three different concentrations of $\mathrm{SnCl}_{2} \cdot 2 \mathrm{H}_{2} \mathrm{O}(10,30$, and 50 $\mu \mathrm{g} / \mathrm{mL}$ ) were tested to reduce ${ }^{99 m} \mathrm{TcO}_{4}^{-} \cdot \mathrm{SnCl}_{2} \cdot 2 \mathrm{H}_{2} \mathrm{O}$ was carefully weighed and diluted in $1 \mathrm{~mL}$ of $\mathrm{HCl} 0.1 \mathrm{~N}$. The solution was added to $50 \mu \mathrm{g}$ of IFN $\alpha 2 \mathrm{~b}$ and $2 \mathrm{mCi}$ of ${ }^{99 \mathrm{~m}} \mathrm{TcO}_{4}^{-}$. The mixture was homogenized and incubated at $37^{\circ} \mathrm{C}$ for $15 \mathrm{~min}$. Purification was done us- ing Sephacryl S-300 HR column. The purity of IFN $\alpha 2 b-$ ${ }^{99 m}$ Tc was checked using paper chromatography with 10 $\mathrm{cm}$ of whatman $3 \mathrm{~mm}$ paper as stationary phase and dry acetone as a mobile phase. Percent of unreduced ${ }^{99 \mathrm{~m}} \mathrm{TcO}_{4}^{-}$ was calculated as follow:

$$
\begin{aligned}
& \% \text { unreduced }{ }^{99 m} \mathrm{TcO}_{4} \\
& =\frac{\text { Activity of }{ }^{99 m} \mathrm{TcO}_{4}^{-}(\mathrm{cps})}{\text { Total activity }(\mathrm{cps})} \times 100 \%
\end{aligned}
$$

Labeling reaction was carried out using optimal condition consisted of $50 \mu \mathrm{g}$ of $\mathrm{SnCl}_{2} \cdot 2 \mathrm{H}_{2} \mathrm{O}, 100 \mu \mathrm{g}$ of IFN $\alpha 2 \mathrm{~b}$ and $10 \mathrm{mCi}$ of ${ }^{99 \mathrm{~m}} \mathrm{TcO}_{4}^{-}$. A similar reaction, but without protein was performed as a control. The mixtures were homogenized, incubated for $15 \mathrm{~min}$, and loaded into Sephacryl S-300 HR column. $0.05 \mathrm{mM}$ of phosphate buffer $\mathrm{pH} 7.4$ was used as elution buffer. $1 \mathrm{~mL}$ of each fraction was collected and measured using dose calibrator (RI Deluxe IsotopCalib II, Victoreen, 139,000 N).

\subsection{Pharmacokinetics Study}

Four groups of animals $(\mathrm{n}=3)$ were used: group received ${ }^{99 \mathrm{~m}}$ Tc-IFN- $\alpha 2 \mathrm{~b}$ mutein C2D, ${ }^{99 \mathrm{~m}} \mathrm{Tc}-\mathrm{IFN}-\alpha 2 \mathrm{~b}$ mutein C99D; ${ }^{99 \mathrm{~m}}$ Tc-IFN- $\alpha 2 \mathrm{~b}$ mutein C2D C99D; and ${ }^{99 \mathrm{~m}}$ Tc-IFN- $\alpha 2 \mathrm{~b}$ wild type. $1 \mathrm{mCi}$ of each radiolabeled interferon was intravenously injected. Blood samples were collected at 5, 10, $15,20,30,45,60,90,120$, and $180 \mathrm{~min}$ after the injection. The samples were weighed and measured using single channel analyzer (ORTEC, 4890). The radioactivity of sample was corrected using Tc99m half-life. Phar- macokinetic analysis of the plasma concentration versus time of radiolabel proteins was performed using the computer program Multifit (version 8/2000, developed by Dr. J. H. Proost, University Center for Pharmacy, Groningen, The Netherlands) with two-compartment model, as described by Rachmawati et al. [13] The plasma concentration curves were fitted from 5 to 180 minutes with the Marquardt algorithm and constant relative error variance model (weighting). An Iterative Two-Stage Bayesian population analysis was applied to obtain the population pharmacokinetic parameters of all interferon alpha $2 b$ forms in normal rat. Initial estimates were obtained from a standard two-stage analysis. It was demonstrated that the final population pharmacokinetic parameters were were fitted to a one and a two-compartment model. The goodness of fit then was assessed by Akaike Information Criterion (AIC), examination of residual variances (CVres) and visual inspection. Visual inspection of the individual data was performed to check the validity of our population analysis. The goodness of fit was best for the 2compartment model.

\subsection{Biodistribution Assay}

Four groups of Swiss mice $(\mathrm{n}=6)$ were used: group received ${ }^{99 \mathrm{~m}}$ Tc-IFN- $\alpha 2 \mathrm{~b}$ wild type; ${ }^{99 \mathrm{~m}} \mathrm{Tc}-\mathrm{IFN}-\alpha 2 \mathrm{~b}$ mutein C99D, ${ }^{99 \mathrm{~m}}$ Tc-IFN- $\alpha 2 \mathrm{~b}$ mutein C2D; and ${ }^{99 \mathrm{~m}}$ Tc-IFN- $\alpha 2 \mathrm{~b}$ mutein C2D C99D. Each group was divided into 2 classes: 10 and $30 \mathrm{~min}$ observations. Each radiolabeled interferon was intravenously injected with dose of $100 \mu \mathrm{Ci}$. The biodistribution of radiolabeled interferons was observed in 2 different periods: 10 and $30 \mathrm{~min}$. After each time period of administration of the radiolabeled protein, the mice were sacrificed. The blood and several organs (liver, kidney, heart, lung, intestine and lymph) were collected and weighed. The radioactivity was measured using single channel analyzer as described previously for pharmacokinetic study.

\subsection{Antiproliferation Assay}

HepG2 cell line was maintained in DMEM containing penicillin, streptomycin, amphotericin $\mathrm{B}$, gentamycin and $10 \%$ heat-inactivated fetal bovine serum (FBS) at $37^{\circ} \mathrm{C}$ in a humidified incubator with $5 \% \mathrm{CO}_{2}$. After $70 \%$ confluency, the adhering cells were washed with PBS and detached using $0.25 \%$ trypsin/EDTA. Cells $\left(6 \times 10^{3} /\right.$ well $)$ were seeded to 96 wells plate and incubated overnight. The medium was replaced by $150 \mu \mathrm{L}$ of fresh medium containing IFN wildtype or muteins (concentration ranged from 0.25 to $5 \mu \mathrm{g} / \mathrm{mL}$ ). Cell in medium alone was used as a negative control. Proliferation of cells was determined at $72 \mathrm{~h}$ after IFN treatment. The cells were washed using PBS and the viable cells were measured based on MTT conversion into formazan by mitochondrial reducetase. $20 \mu \mathrm{L}$ of MTT solution $(5 \mathrm{mg} / \mathrm{mL})$ was added to 
each well and incubated for $3 \mathrm{~h}$. The medium was discarded and insoluble formazan crystals were dissolved in $200 \mu \mathrm{L}$ of dimethyl sulfoxide. The plate was shaked for $1 \mathrm{~min}$ and absorbance was measuredd at $515 \mathrm{~nm}$. The assay was analyzed in three dependent experiments.

\subsection{Statistical Analyses}

All data were analyzed with SPSS program. Statistical differences between the control and IFN-treated groups were calculated by unpaired student's t-test and considered significant at $\mathrm{P}<0.05$.

\section{RESULT}

\subsection{Site-Directed Mutagenesis}

The sequences of the oligonucleotides used in PCR based
SDM was presented in Table 1. By using LB agar containing ampicillin selection, there were 60 transformants identified at first SDM step. Five recombinant plasmids were isolated and characterized. Migration analysis showed that all recombinant plasmids had similar size to wildtype (Figure 1(a)). Single digestion analysis using EcoRI or HindIII gave single band with $6.4 \mathrm{~kb}$ in size as expected (Figure 1(b)). Nucleotide analysis was performed to determine whether the recombinant plasmids contained the mutated hIFN $\alpha 2$ b ORF. Using Seqman DNA Star alignment software, the sequences data confirmed that four plasmids harbored desired nucleotide change without any additional mutation (Figure 2). These recombinant plasmids were used as templates for second SDM step.

At second SDM step, it produced 70 transformants from each template. Five of them were characterized by mi-

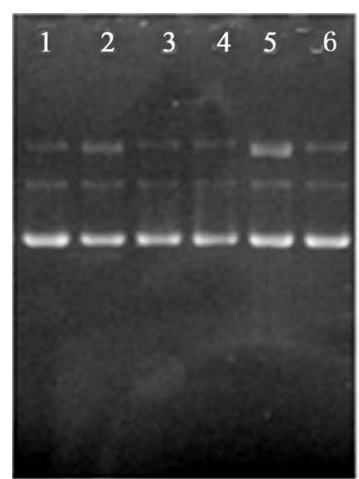

(a)

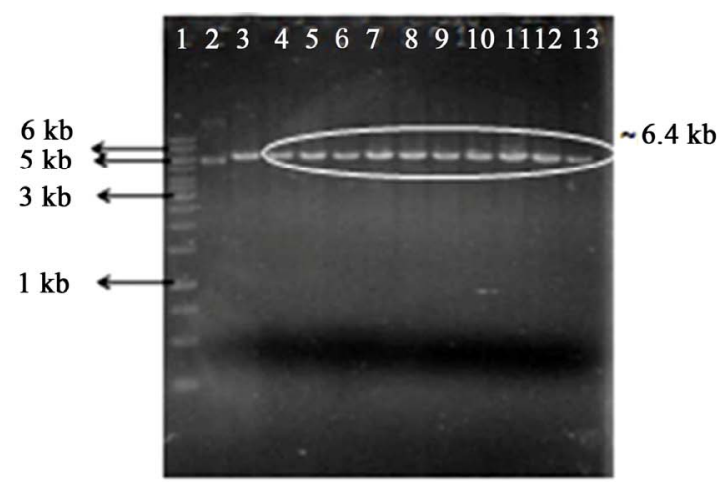

(b)

Figure 1. Characterization of recombinant plasmids (a) Migration analysis: lane $1=$ pET32bhIFN $\alpha 2$ b wildtype, lanes $2-6=$ recombinant plasmids isolated from transformants; (b) Digestion analysis: lane $1=$ DNA marker, lane $2=$ pET32b-hIFN $\alpha 2 b$ wildtype uncut, lane $3=$ pET32bhIFN $\alpha 2$ b wildtype cut by $E c o$ RI, lanes $4-8=$ recombinant plasmids isolated from transformants cut by $E c o$ RI, lanes $9-13$ = recombinant plasmids isolated from transformants cut by EcoRI.

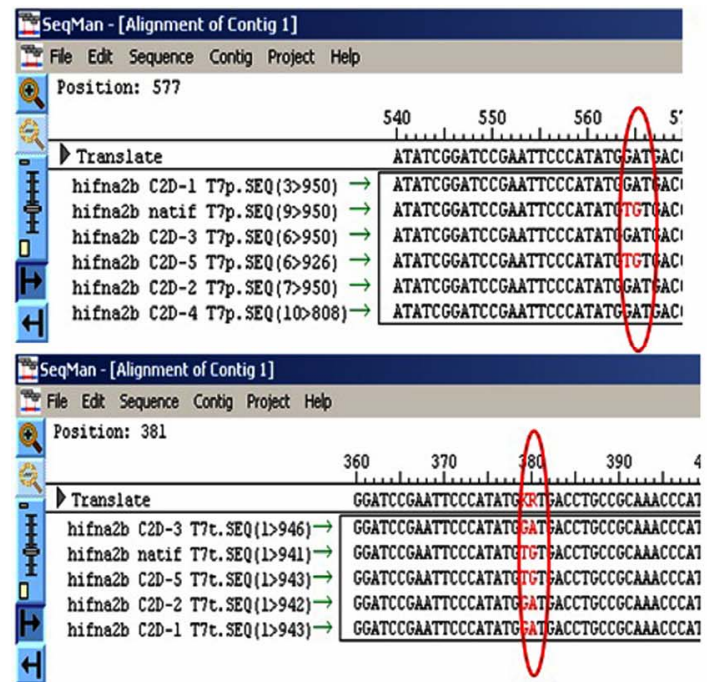

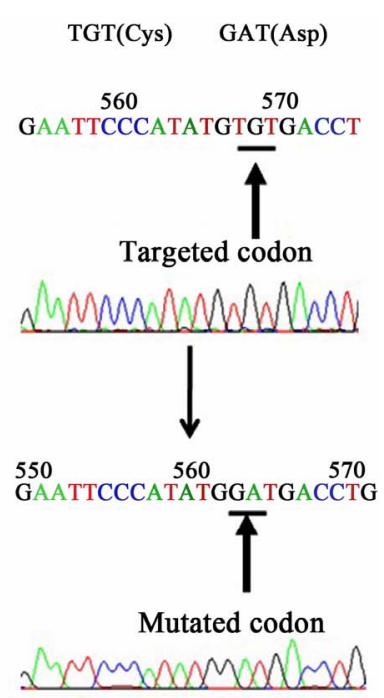

Figure 2. Nucleotide sequence analysis of transformants recombinant plasmid resulted from first SDM step using T7 promoter and terminator primers. 
gration and single digestion analyses. All recombinants plasmid showed similar size to the wildtype with $6.4 \mathrm{~kb}$ in size (data not shown). Nucleotide sequence analysis showed that four plasmids from each template have been successfully mutated without any undesired mutation (Figure 3). The two steps PCR-based SDM resulted

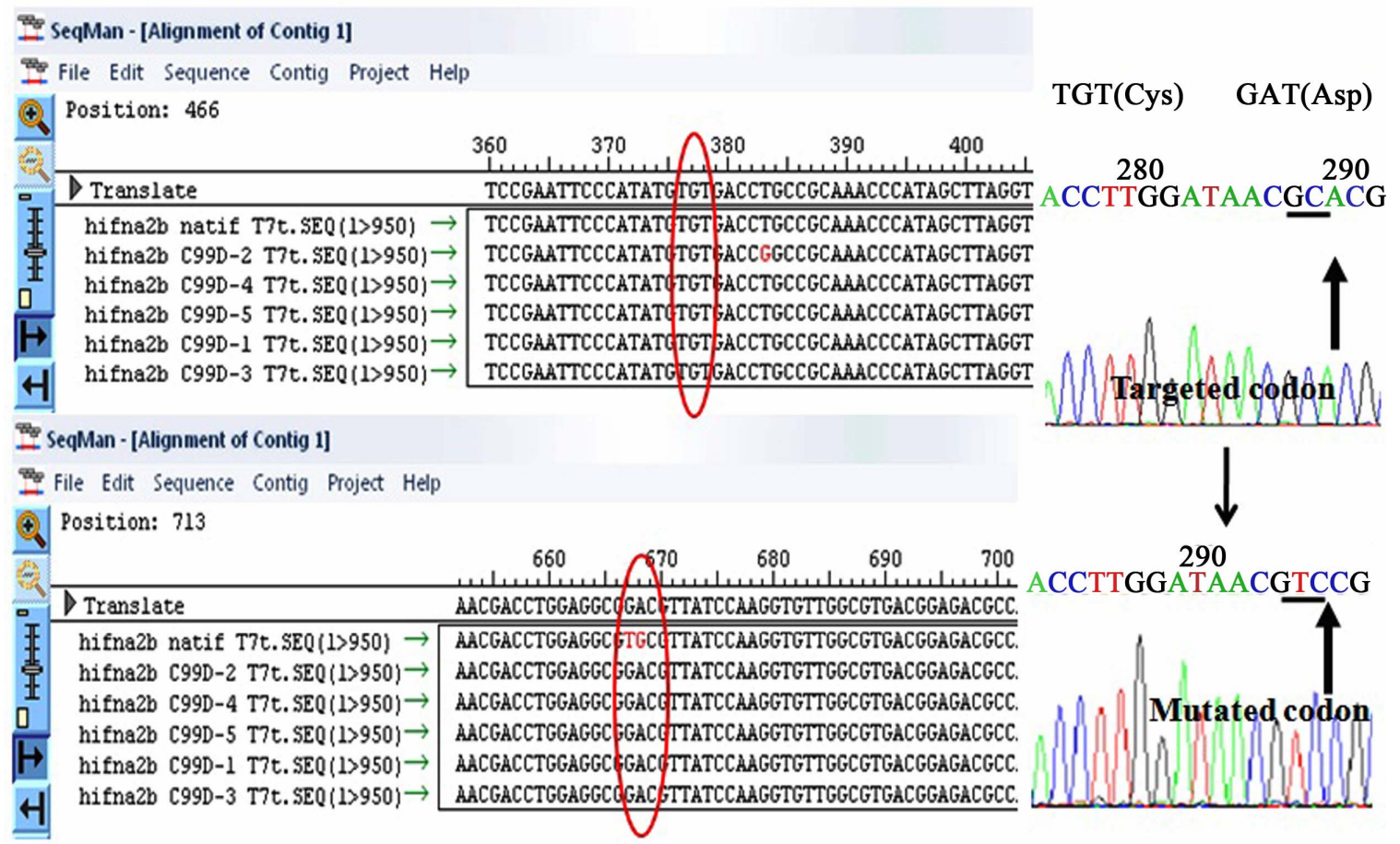

(a)

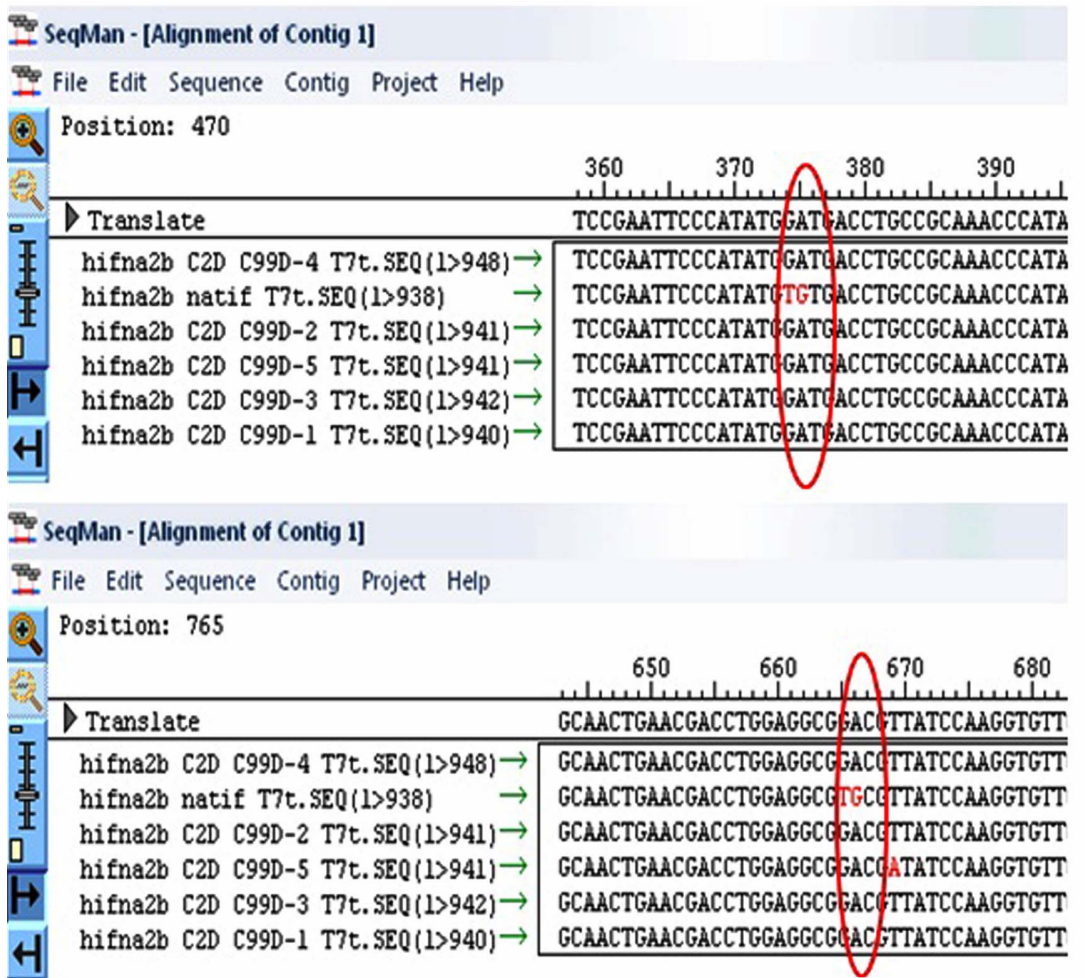

$$
\begin{aligned}
\text { TGT(Cys) } & \rightarrow \text { GAT(Asp) } \\
\text { TGC(Cys) } & \rightarrow \text { GAC(Asp) }
\end{aligned}
$$

280 290
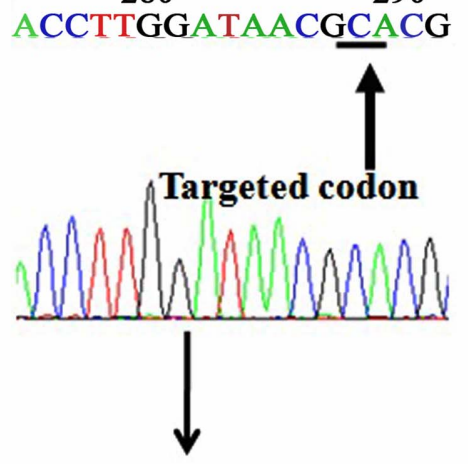

290

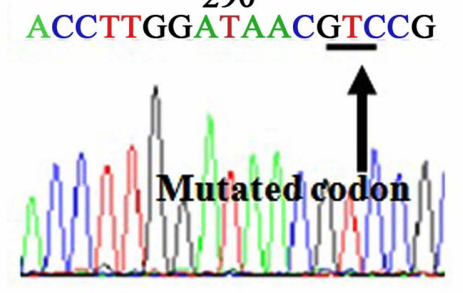

(b)

Figure 3. Nucleotide sequence analysis of transformants recombinant plasmid resulted from second SDM using T7 terminator primers: (a) pET32b-hIFN 2 $2 b$ as a template; (b) pET32b- $h I F N \alpha 2 b$ C2D as a template. 
in three mutated recombinant plasmids: pET32b-hIFN $\alpha 2 b$ C2D, pET32b-hIFN $\alpha 2 b$ C99D, and pET32b-hIFN $\alpha 2 b$ C2D C99D.

\subsection{Protein Overproduction, Purification and Characterization}

All mutated recombinant plasmids were transformed into E. coli BL21 (DE3) to express the ORFs. The overproduction was done at $25^{\circ} \mathrm{C}$ for $3 \mathrm{~h}$ with $200 \mathrm{rpm}$ vigorous shaking and $0.5 \mathrm{mM}$ IPTG. Total proteins were characterized in 15\% SDS PAGE. As shown in Figure 4(a), at induced condition, all muteins showed similar band size (about $37 \mathrm{kDa}$ ) to wildtype form. The muteins were purified using nickel affinity column to obtain soluble protein (Figure 4(b)) as well as isolated IB (Figure 4(c)). The muteins amount both as soluble and IB were measured by Bradford assay. The muteins yield was ranging from $8.7-8.9 \mathrm{mg} / \mathrm{L}$ culture as soluble with $14 \%-15 \%$ recovery and $28.7-28.8 \mathrm{mg} / \mathrm{L}$ culture as solubilized IB with $50 \%-51 \%$ recovery. The renaturation of solubilized IB was performed according to previous work [12]. Based on non reducing SDS PAGE result, it was shown that solubilized IB was refolded partially. Characterization of the muteins conformation using non denaturing PAGE showed that the wildtype form gave two different conformations (Figure 5 lane 1) as also shown by mutein C2D and C99D. In contrast, mutein C2D C99D showed one band indicating that only one conformation was resulted.

\subsection{IFN $\alpha 2 b$ Radiolabeling}

Pure ${ }^{99 \mathrm{~m}} \mathrm{Tc}-\mathrm{IFN} \alpha 2 \mathrm{~b}$ with free $\mathrm{TcO}_{4}^{-}$was shown on paper chromatograph (Figure 6). The most appropriate concentration of $\mathrm{SnCl}_{2} \cdot 2 \mathrm{H}_{2} \mathrm{O}$ to reduce $\mathrm{TcO}_{4}^{-}$was achieved at $50 \mu \mathrm{g} / \mathrm{mL}$ (Table 2). To remove $\mathrm{TcO}_{2}$ and $\mathrm{TcO}_{4}^{-}$ after radiolabeling, Sephacryl HR-300 column was used as shown in Figure 7 which represented wildtype form. Similar chromatograms were observed for all muteins (data not shown). Protein characterization of fraction number 10 - 15 using SDS-PAGE showed IFN $\alpha 2 \mathrm{~b}$ band corresponding to $37 \mathrm{kDa}$ size.

\subsection{Pharmacokinetics Study}

Blood protein concentration as a function of time was shown in Figure 8. As depicted in that figure, all mutein forms showed similar profile as the wildtype form but had longer elimination half-life $(\mathrm{p}<0.05), 178 \mathrm{~min}$ (C2D), 118 min (C99D), 184 min (C2DC99D), and 57 min (wildtype) respectively.

\subsection{Biodistribution Assay}

After 10 min of intravenous administration, only mutein C2DC99D showed highest accumulation in liver (Figure 9(a)) and showed highest blood accumulation after 30 min of injection $(p<0.05)$. All mutein forms showed higher renal distribution especially at $10 \min (\mathrm{p}<0.05)$.

\subsection{Antiproliferation Assay}

As shown in Figure 10, although a dose-dependent activity, no significant different on the antiproliferation effect was observed between wildtype and muteins at all concentration tested.

\section{DISCUSSION}

Several strategies have been reported to obtain mutation using site-directed mutagenesis. In this study, we applied mutagenic overlapping primers to introduce mutation on our recombinant hIFN $\alpha 2 \mathrm{~b}$. The mutagenic primers were

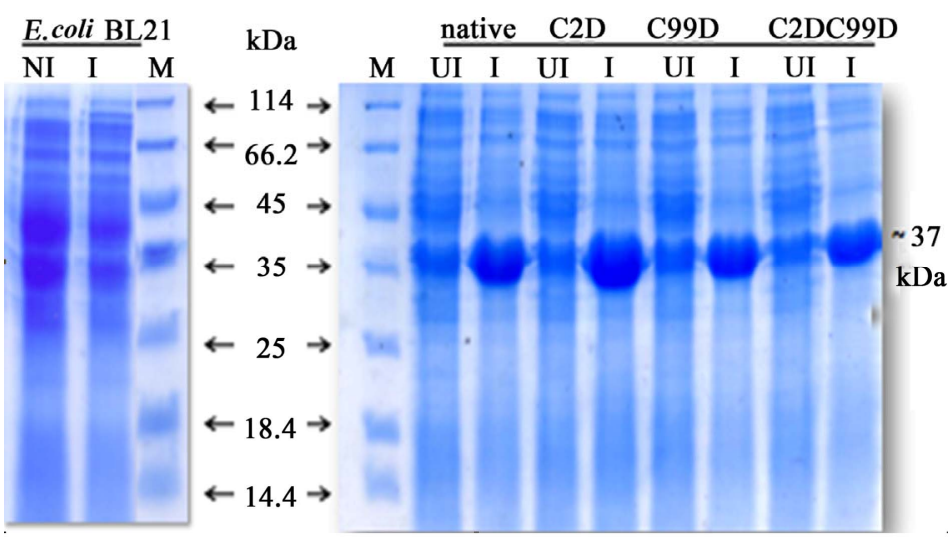

(a)

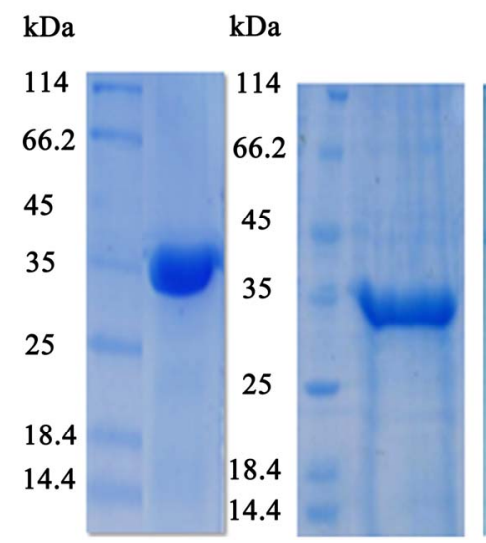

(b)

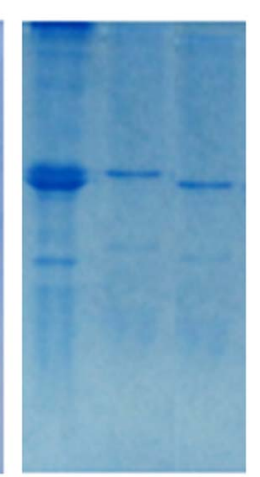

(d)

Figure 4. Muteins characterization by SDS PAGE. (a) Total protein of muteins at induced (I) and uninduced (UI) conditions with total protein of E. coli BL21(DE3) as a standard; (b) and (c) Purified soluble protein and solubilized IFNa2b C2D from IB; (d) Renatured IFN $\alpha 2 \mathrm{~b}$ C2D from IB: lane $1=$ renatured protein, lane $2=$ reduced soluble protein and lane $3=$ unreduced soluble protein (for IFN $\alpha 2 b$ C99D and IFN $\alpha 2$ b C2D C99D data were not shown). 


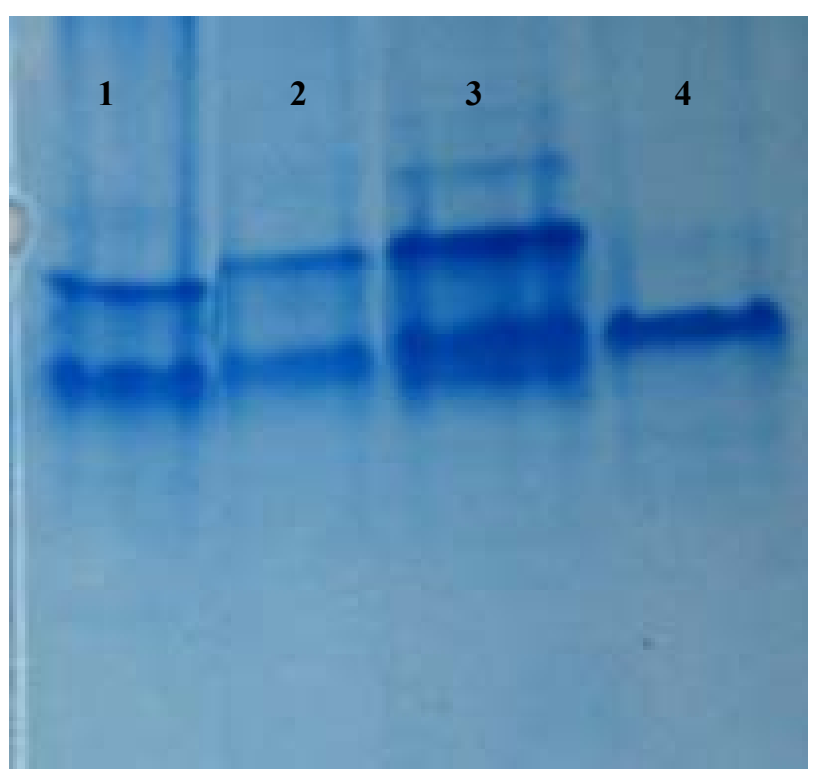

Figure 5. Muteins characterization by native PAGE. Lane $1=$ wildtype, lane $2=$ mutein $\mathrm{C} 2 \mathrm{D}$, lane $3=$ mutein $\mathrm{C} 99 \mathrm{D}$ and lane $4=$ C2D C99D.

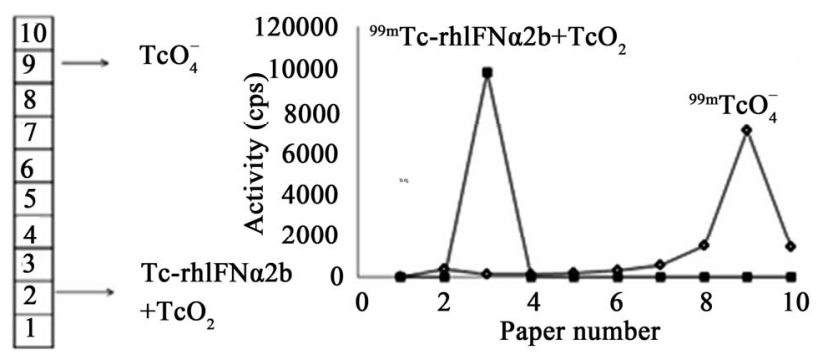

Figure 6. Paper chromatograph of labeled interferon. The $\mathrm{TcO}_{4}^{-}$peak was only detected in a standard reaction.

Table 2. The yield of radiolabel interferon using different concentrations of reducing agent.

\begin{tabular}{ccc}
\hline $\mathrm{SnCl}_{2} 2 \mathrm{H}_{2} \mathrm{O}(\mu \mathrm{g} / \mathrm{mL})$ & $\mathrm{TcO}_{4}^{-}(\%)$ & ${ }^{99 \mathrm{~m}} \mathrm{Tc}-\mathrm{IFN} \alpha 2 \mathrm{~b}+\mathrm{TcO}_{2}(\%)$ \\
\hline 10 & 3.73 & 96.20 \\
30 & 3.54 & 96.46 \\
50 & 0.36 & 99.64 \\
\hline
\end{tabular}

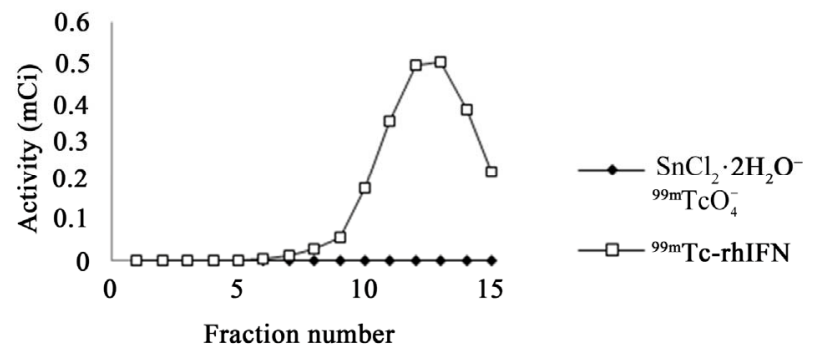

Figure 7. Chromatogram of labeled ${ }^{99 \mathrm{~m}} \mathrm{Tc}-\mathrm{IFN} \alpha 2 \mathrm{~b}$ after applying through size exclusion Sephacryl HR-300 column.

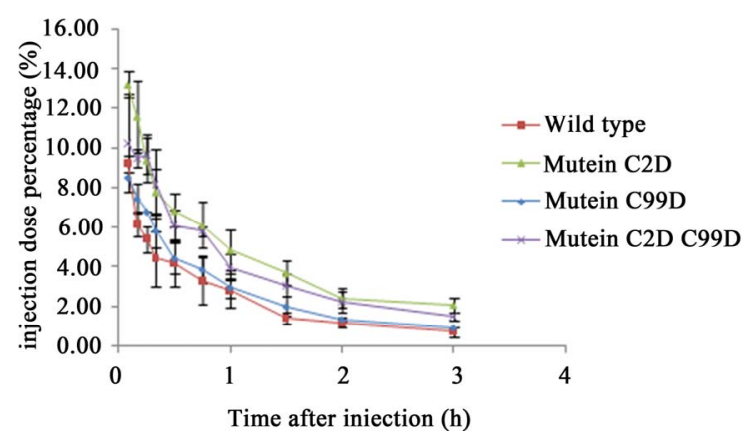

Figure 8. Blood protein concentration as a function of time after intravenous injection of radiolabel proteins.

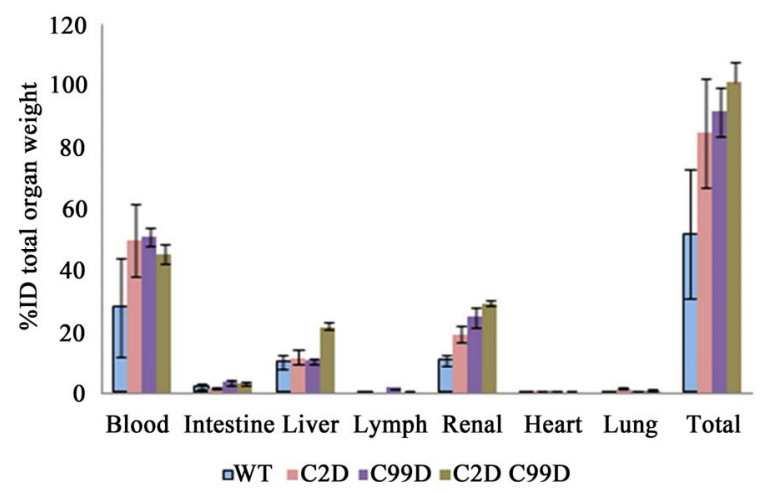

(a)

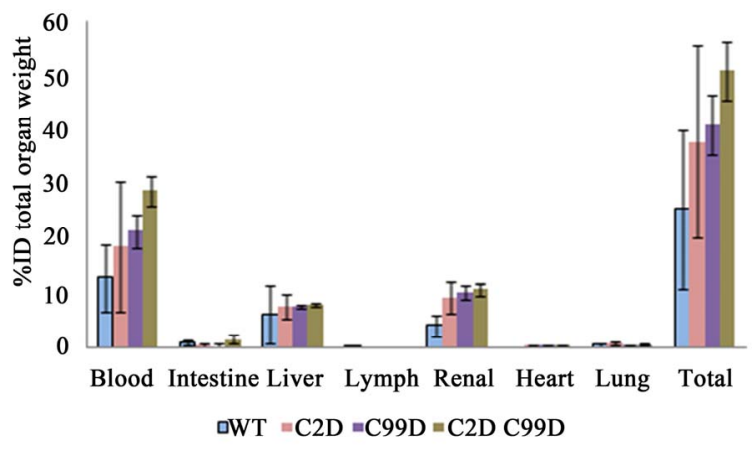

(b)

Figure 9. Biodistribution profile of wildtype and mutein forms of ${ }^{99 \mathrm{~m}} \mathrm{Tc}-\mathrm{hIFN} \alpha 2 \mathrm{~b}$. (a) 10 minutes after administration; (b) 30 minutes after administration.

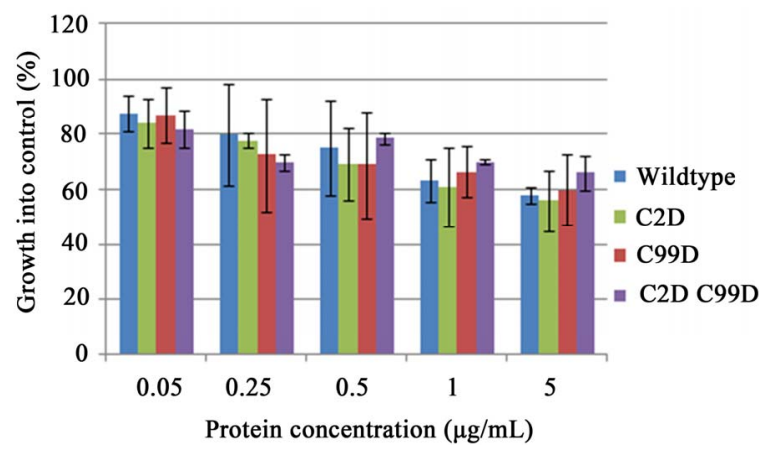

Figure 10. Antiproliferation analysis of interferon alpha2b in HepG2 cells. 
designed using pET32b-hIFN $\alpha 2 \mathrm{~b}$ sequence as a template with following consideration: both primers contained desired mutation and annealed to the same sequence of opposite strand, have 25 - $26 \mathrm{bps}$ in length, and have desired mutation in the middle of primer sequences. To increase sequence fidelity, $P f u$ DNA polymerase enzyme which has 3' - 5' exonuclease activity was used. Nucleotide sequence analysis confirmed that most recombinant plasmids $(80 \%)$ carrying desired mutation with no undesired mutation, $13 \%$ showed undesired mutation and only $7 \%$ of recombinant plasmids showed no mutation. This means, the efficiency of our method was $80 \%$. This result was in agreement with Hemsley [14] which also claimed $80 \%$ efficiency. The presence of undesired mutation (13\%) can be due to the lack of $P f u$ fidelity. It was reported that $P f u$ error rate was $1.3 \times 10^{-6}$, but Cline [15] observed that the error rate depended on PCR reaction, such as concentration of dNTPs $(100-300 \mu \mathrm{M})$ and $\mathrm{MgSO}_{4}(2-3$ $\mathrm{mM})$ at certain $\mathrm{pH}(8.5$ - 9.1). Out from those conditions, the error rate can be 40 -fold higher. The higher dNTPs concentration $(400 \mu \mathrm{M})$ we used in this study seems to be good condition during PCR reaction. As a result, unfortunately unexpected additional mutations were observed (13\%).

When the mutated plasmids obtained were overproduced, the yield and recovery of muteins as soluble and IB were not significanty different as compared to wildtype form [12]. In addition, the refolded muteins showed similar result to the wild type indicating that the substitution did not have any effect on the protein solubility. Characterization using native PAGE showed two different conformations on the wild type form. Disulfide interchange suggested to be responsible for this different which resulted in unexpected conformation. Changing only one of two cysteins residues involved in this interchange conformation did not prevent the interchange conformation. However, when both cysteins were substituted, unexpected conformation was eliminated, indicating the disulfide interchange was disappeared. The denaturing SDS PAGE (data not shown) confirmed that all muteins had the same size $(37 \mathrm{kDa})$ with the wild type indicating that no significant change of molecular weight.

The benefit of amino acid substitution on hIFN $\alpha 2 b$ we reported here was shown, in particular in the plasma halflife, as well as in the biodistribution profile alterations. Although no change in the pattern of plasma concentration vs time curve, mutein forms of hIFN $\alpha 2 b$ revealed longer circulation time as compared to wild type form (Figure 8). Both wild type and mutein forms of hIFN $22 \mathrm{~b}$ showed biphasic curve which indicated that the proteins have a two-compartment model of pharmacokinetic. Improving the circulation time of mutein hIFN $\alpha 2 \mathrm{bs}$, although minor, seems to be a charge-dependent. Substituting the cysteine residue with aspartic acid resulted in improved net negative charge of the hIFN $\alpha 2 b$ as shown in our calculated PI value (6.26 for wild type, 5.71 for one point mutation, and 5.31 for 2 points mutation, respectively). The charge selective of renal filtration seems to be one of responsible parameters for the plasma half-life enhancement of the muteins. Size selective renal filtration seems not to be responsible to this phenomenon as we observed no size different between wildtype and muteins as confirmed by size exclusion chromatogram (Figure 7). The glome rular basement membrane (GBM) which functions as a filter is covered by negatively charged matrix proteins: GBM-sulfate proteoglycans, i.e. agrin and perlecan. These matrix layers contribute to an anionic GBM barrier. The endothelial and podocytes may also form a part of a negative filtration barrier by membrane bound sulfate protteoglycan on their surface $[16,17]$. Although the mutein forms we developed did not result in superior improvement in the plasma half-life of hIFN $\alpha 2 b$ as compared to other groups [3-5], our approach is the first to report the successful amino acid substitution in relation to the plasma half-life improvement of hIFN $\alpha 2 b$. In addition, two points mutation of hIFN $22 \mathrm{~b}$ (C2D C99D mutein) showed higher liver uptake after $10 \mathrm{~min}$ of protein injection among other hIFN $\alpha 2$ bs we studied, although minor. Renal accumulation increased significantly in all mutein forms as compared to wildtype, especially at 10 $\mathrm{min}$. Decreasing accumulation both in liver and kidney at 30 min may due to redistribution to the blood as shown in Figure 9. As early interpretation, this seems to be charge-dependent uptake. Although ambiguous, our data on renal accumulation of mutein forms (Figure 9) was in line with Yamasaki et al. [18] result which reported high renal accumulation of aconitylated BSA, the more negative charge of BSA. Further careful study must be performed to strengthen our biodistribution data.

Surprisingly, substitution of cysteins group with aspartic acids resulted in maintaining the activity of interferon with IC50 on both wild type and muteins interferon alpha2b was $>5 \mu \mathrm{g} / \mathrm{mL}$ as shown in our preliminary in vitro data using $\mathrm{HepG}_{2}$ cells. This report confirmed the finding described by Inamura [19] and Tnani [20].

\section{CONCLUSION}

The muteins were successfully constructed and produced as $37 \mathrm{kDa}$ fusion protein containing thioredoxin tag at its $\mathrm{N}$ terminus. The yields of muteins were ranging $8.8-8.9$ $\mathrm{mg} / \mathrm{L}$ from soluble protein and 22.8 - 22.9 from inclusion bodies. All muteins showed longer plasma circulation than the wild type form. In addition to the plasma half-life, the cysteineto aspartic acid substitution of hIFN $\alpha 2 \mathrm{~b}$ did not diminish the activity. Although the charge of hIFN $\alpha 2 b$ seems to be one of responsible parameters for the fate of $\mathrm{hIFN} \alpha 2 \mathrm{~b}$ in vivo, further careful study is still required to confirm our finding. 


\section{ACKNOWLEDGEMENTS}

This research was financially supported by Indonesian Toray Science Foundation (2009) and Incentive Research, Ministry of Research and Technology Indonesia 2009.

\section{REFERENCES}

[1] Jonasch, E. and Haluska, F.G. (2000) IFN in oncological practice: Review of IFN biology, clinical applications, and toxicities. The Oncologist, 6, 34-55. doi:10.1634/theoncologist.6-1-34.

[2] Nyman, T.A., Kalkkinen, N., Tolo, H., et al. (1998) Structural characterization of N-linked and O-linked oligosaccharides derived from Interferon- $\alpha 2 b$ and Interferon- $\alpha 14 \mathrm{c}$ produced by Sendai-Virus-induced human peripheral blood leucocytes. European Journal of Biochemistry, 253, 485-493. doi:10.1046/j.1432-1327.1998.2530485.X

[3] Wang, Y.S., Youngster, S., Grace, M., et al. (2002) Structural and biological characterization of pegylated recombinant interferon alpha- $2 \mathrm{~b}$ and its therapeutic implications. Advance Drug Delivery Review, 54, 547-570. doi:10.1016/S0169-409X(02)00027-3

[4] Ceaglio, N., Etcheverrigaray, M., Kratje, R., et al. (2008) Novel long-lasting interferon alpha derivatives designed by glycoengineering. Biochimie, 90, 437-449. doi:1016/j.biochi.2007.10.013

[5] Subramanian, M.G., Fiscella, M., Smith, A.L. et al. (2007) Albinterferon $\alpha-2 \mathrm{~b}$ : A genetic fusion protein for the treatment of chronic hepatitis C. Nature Biotechnology, 25, 1411-1419. doi:10.1038/nbt1364.

[6] Retnoningrum, D.S., Ningrum, R.A., Kurniawan, Y.N., et al. (2010) Construction of synthetic open reading frame encoding human interferon alpha $2 \mathrm{~b}$ for high expression in Escherichia coli and characterization of its gene product. Journal of Biotechnology, 145, 193-198. doi:10/1016/j.biotec2009.11.008

[7] Radhakrishnan, R., Walter, L.J., Hruza, A., et al. (1996) Zinc mediated dimer of human interferon-a2b revealed by X-ray crystallography. Structure, 4, 1453-1463. doi:10.1016/SO969-2126(96)00152-9

[8] Weissmann, C. and Weber, H. (1986) The interferon genes. Progress Nucleic Acid Research Molecular Biology, 33, 251-300.

[9] Neves, F.O., Ho, P.L., Raw, I., et al. (2004) Overexpression of a synthetic gene encoding human alpha interferon in Escherichia coli. Protein Expression and Purification, 35, 353-359. doi:10.1016/j.pep.2004.02.005.

[10] Wu, Z., Podust, L.M. and Guengerich, F.P. (2005) Ex- pansion of substrate specificity of cytochrome P450 2A6 by random and site-directed mutagenesis. The Journal of Biologycal Chemistry, 280, 41090-41100. doi:10.1074/jbc.MS08182200

[11] Ling, M.M. and Robinson, B.H. (1998) Review: Approaches to DNA mutagenesis. Analytical Biochemistry, 254, 157-178. doi:10.1006/abio.1997.2428

[12] Ningrum, R.A., Retnoningrum, D.S., Sumirtapura, Y.C., et al. (2011) Optimization of human interferon alpha2b soluble protein overproduction and primary recovery of its inclusion bodies. Microbiology Indonesia, 5, 27-32.

[13] Rachmawati, H., Beljaars, L., Reker-Smit, C., et al. (2004) Pharmakokinetic and biodistribution profile of recombinant human interleukin 10 following intravenous administration in rats with extensive liver fibrosis. Pharmaceutical Research, 21, 2072-2078. doi:10.1023/B:PHAM.0000048199.94510.b0.

[14] Hemsley, A., Arnheim, N., Toney, M.D., et al. (1989) A simple method for site-directed mutagenesis using the polymerase chain reaction. Nucleic Acid Research, 17, 6545-6551. doi:10.1093/nar/17.21.8915

[15] Cline, J., Braman, J.C. and Hogrefe, H.H. (1996) PCR fidelity of $P f u$ DNA polymerase and other thermostable DNA polymerases. Nucleic Acid Research, 24, 35463551.

[16] Kanwar, F. and Danesh, F. (2007) Contribution of proteoglycans towards the integrated functions of renal glomerular capillaries a historical perspective. The American Journal of Pathology, 171, 9-13. doi:10.2353/ajpath.2007.070356.

[17] Trygvason, K. and Wartiovaara, J. (2005) How does the kidney filter plasma. Physiology, 20, 96-101. doi:10.1152/physiol.00045.2004

[18] Yamasaki, Y., Hisazumi, J., Yamaoka, K., et al. (2003) Efficient scavenger mediated hepatic targeting protein by introduction of negative charges on the proteins by aconitylation: The influence of charge density and size of the proteins molecule. European Journal of Pharmaceutical Science, 18, 305-312. doi:10.1016/S0928-0987(03)00021-6.

[19] Inamura, K., Matsuzaki, Y.M., Uematsu, N., et al. (2005) Rapid inhibition of MAPK signaling and anti-proliferation effect viaJAK/STAT signaling by interferon- $\alpha$ in hepatocellular carcinoma cell lines. Biochimica et Biophysica Acta, 1745, 401-410. doi:10.1016/j.bbamcr.2005.06.003

[20] Tnani, M. and Bayard, B.A. (1999) Evidence for IRF-1 dependent gene expression deficiency in interferon unresponsive HepG2 cells. Biochimica et Biophysica Acta, 1451, 59-72. doi:10.1016/S0167-4889(99)00089-0. 